\title{
Students' Voices Towards Online Debate Through WhatsApp as Alternative Media to Enhance Critical Thinking Skills During Covid-19 Pandemic
}

\author{
https://doi.org/10.3991/ijim.v15i05.18759 \\ Pahmi $\left.{ }^{(}\right)$, Siti Niah \\ Universitas Muhammadiyah Riau, Pekanbaru, Indonesia \\ pahmi@umri.ac.id
}

\begin{abstract}
Many studies emphasize the importance of preparing students with critical thinking skills, and these skills can be honed through classroom debate. During Covid-19 pandemic, however, it is impossible to carry out classroom debate. Therefore, this study focused on online debate through WhatsApp. Specifically, the present study aimed at finding out students' voices towards online debate through WhatsApp as alternative media to enhance critical thinking skills during Covid-19 pandemic. 17 undergraduate students participated in online debate for ten sessions throughout one whole semester. At the end of the research, 17 participants completed the survey questionnaires and 8 students volunteered to participate in semi-structured interviews. The results from both quantitative and qualitative data revealed that the participants found critical thinking skills important. Furthermore, the respondents believed that the online debate was good learning media to help them improve their critical thinking skills during this Covid-19 pandemic. The activity provided flexibility in terms of time and place. Other advantages, as claimed by the participants, included reducing students' anxiety, improving teamwork skills, and improving persuasion skills. However, some barriers were also found based on the participants' responses. The participants were concerned with the issue of being distracted, tendency to copy and paste, unstable network, and limited time.
\end{abstract}

Keywords—students' voices, online debate, critical thinking skills, covid-19 pandemic

\section{Introduction}

There have been an increasing number of studies focusing on improving students' critical thinking skills. The skills need to be possessed by students in the $21^{\text {st }}$ century [1] [2] since they play a pivotal role for students both in the classroom and in the work field. Having critical thinking skills allows students to learn more effectively because they will be able to actively analyze, discuss, and apply content [3] during the learning process. Furthermore, it is important for students to gain knowledge and be able to apply it into real life [4]. This can be gained if the students have critical thinking skills. 
However, the problem especially in Indonesia is that teachers pay less attention to critical thinking skills [5]. As a result, many students have low critical thinking skills [6] (Kurniawati, Zubaidah, \& Mahanal, 2015 as cited in [7]. Hence, they are unable to analyze and criticize the topics being discussed and tend to be reluctant in sharing their opinions during the learning (Masduqi, 2011 as cited in [8].

This situation leads to a bad indication due to the fact that critical thinking skills will help students succeed in the work field [7] once graduating from the university. Being encountered with situations that require them to analyze the situation to find a solution is something inevitable. Therefore, the students will certainly have difficulty in solving and finding solutions to an issue they are facing without having the ability to think critically.

As was known that having critical thinking skills is not something the students can acquire easily [9]. The students need to practice the skills continuously [10]. Hence, it is of high importance for teachers to teach the skills to the students either individually or inserted in the lecture [5]. In addition, preparing university graduates to be ready for global competition makes critical thinking skills imperative [9].

According to the Minister of Education and Culture of Indonesia regulation number 20 of 2016, it is the responsibility of Indonesian teachers to help improve students' critical thinking skills [11]. To help enhance students' critical thinking skills, teachers can apply various methods, one of which is by facilitating debate where students are provided with a hot issue. The students then need to analyze the issue from various viewpoints. After that, they must find a solution to cope with the problem being discussed.

On the other side, the global spread of Covid-19 has become a serious problem since it has significantly affected human's life, including in Indonesia. Data from [12] reveal that the first case of COVID-19 was detected on 2 March 2020. As of 3 September 2020, the number of confirmed Covid-19 cases based on the data from the Ministry of Health of the Republic of Indonesia has reached more than 184,000. This number seems to keep increasing every day, and this situation inevitably influences all sectors, including education.

In such current situation, both teachers and students cannot go to schools or universities having face-to-face meetings. This is due to the policy by the government following the suggestion from World Health Organization to shut down schools and universities in Indonesia [13]. In fact, the closure of schools has been carried out since the beginning of March 2020 as a way to prevent the spread of Covid-19 in Indonesia [12]. As a response to class suspensions due to the spread of Covid-19 pandemic, teachers need to facilitate online learning [14]. Therefore, the Minister of Education and Culture of the Republic of Indonesia has instructed all educational institutions to move from face-to-face class into online class due to the increasing spread of Covid19 all over Indonesia since 24 March 2020 [15].

Online learning, in this case facilitating online debate, by utilizing various apps seems to be the best option because classroom debate seems impossible referring to the government policy to carry out online learning as a replacement of face-to-face learning at least for the time being. Yemeni EFL learners in India, for example, rely on YouTube, Zoom, Blogs, Twitter, WhatsApp, Facebook, and so forth for online 
learning [16]. Therefore, this research focused on online debate using WhatsApp. This app was chosen since most students in Indonesia can get access to the Internet and use WhatsApp in their daily life.

Regarding the use of debate, previous studies have demonstrated that debates can help improve students' critical thinking skills [3] [8] [17]. However, most debates carried out are conventional debates taking place in the classroom. Not much research has examined the online debate, specifically utilizing WhatsApp. Having seen the current problem due to Covid-19 pandemic and the importance to keep training students about critical thinking skills, the present research contributes by enriching the knowledge of how teachers can facilitate online debate through WhatsApp in a sudden and completely unprepared situation due to the COVID-19 pandemic in order to enhance students' critical thinking skills. Furthermore, this research also sheds some lights on the benefits as well as challenges the students encounter during their practices of carrying out online debate. Therefore, questions leading the present research are:

1. What do students think of online debates through WhatsApp during Covid-19 pandemic?

2. Do they think the online debate helps improve their critical thinking skills during Covid-19 pandemic?

3. What challenges do the students encounter when participating in online debate during Covid-19 pandemic?

\section{$2 \quad$ Literature Review}

This part presents some theoretical concepts in relation to students' voices towards online debate as alternative media to enhance students' critical thinking skills during Covid-19 Pandemic in Indonesia. The concepts include critical thinking skills and debate.

\subsection{Critical Thinking Skills}

In order to support campus life and in the work field once graduating from university, students need to have various skills. One very important skill the students need to have is the ability to think critically [17] and this is a concern of the Indonesian government. According to the Minister of Education and Culture of Indonesia regulation number 20 of 2016, it is the responsibility of Indonesian teachers to help improve students' critical thinking skills [11]. There are several definitions of critical thinking. It is defined as the ability to argue in an organized manner and to systematically evaluate other people's arguments [3]. That is why, critical thinking skills are very important to be enhanced by today's students.

Those with critical thinking skills will experience six stages when being encountered with a problem or issue. They will first of all do some research to create arguments, organize the arguments, analyze all assumptions, collect evidence to support the arguments, evaluate the evidence, and convey the arguments to others (Patterson, 2011 as cited in [18]. 
A simpler definition by Rybold (2006) as cited by [8] point out that when we argue and defend our ideas, we include people with critical thinking categories. On another occasion, we are also said to be people who think critically when we are able to change the attitude of others with the arguments and evidence that we present [8]. Critical thinking, in fact, is a complex process which encourages people to use knowledge to solve problems, make decisions, analyze all assumptions, conduct investigations or research to produce scientific information or conclusions [19].

Developing critical thinking skills is of high importance for today's students [20] since these skills are considered as one of the most important skills in this era [21]. The skills deal with various areas such as problem solving [22]. Having the skills enable students to evaluate and regulate useful and purposeful arguments in the form of an interpretation, analysis, evaluation, and inference [7] [21].

\subsection{Debate}

Through debate, students have the opportunity to practice critical thinking skills because the students will learn to express opinions and convince listeners. In addition, students are required to find ways to defend their opinions by finding data and evidence. Debate also allows student to experience active learning. This kind of learning can be used to develop critical thinking skills where students actively participate in the learning activities arguing and defending their position [3].

Debate is believed to be an active learning tool promoting critical thinking (Darby, 2007 as cited in [23]. Halvorsen (2005) in [8] further reveal that the debate activity requires students to look at an issue that is being discussed from various sides. Furthermore, students are required to analyze the arguments of opponents, think of ways to refute these arguments with strong data. These all activities certainly require critical thinking skills and can be honed through debate. Therefore, debate activity can significantly improve students' critical thinking skill [8] [24].

\subsection{Previously Relevant Research}

Previous research has proven that debate is a very helpful method in improving students' critical thinking skills. Even the students involved believed that debate helped improve their critical thinking skills [17]. Other research results show that in addition to helping students improve their critical thinking skills, debate provides students with space to practice their work skills in teams and increase self-confidence [17]. The ability to work in teams and have confidence will be very useful for students when they are in the work field.

However, almost all research on debate focused on conventional debates where the teacher facilitated debate in the classroom. Not much research has been done about facilitating online debate. The present research, on the other hand, employs WhatsApp to facilitate online debate since the current Covid-19 pandemic prevents classroom debate.

As was known that today's teaching and learning process can be facilitated by utilizing technology in order to improve student's performances [25]. Utilizing technol- 
ogy can help students increase their skills [26]. In addition, using technology to support teaching and learning provides a more flexible interaction and communication among students [27]. But successful interaction and collaboration requires the participants to have IT competency [28].

In recent years, there has been a growing interest among educators to use mobile phones for teaching and learning process [29]. Learning through mobile devices allows students to get information quickly and be able to learn anywhere anytime [30]. Students can access the learning material easily [28].

Now the question lies in the selection of the best mobile apps to use to facilitate the learning process. [31] argue that it is quite problematic to select the most appropriate educational apps for students. One consideration is related to students' age (Papadakis et all, 2019 as cited in [32]. In the context of the present study, WhatsApp was chosen because this app is one of the best options to facilitate online learning. A research by [25] reveals that students view WhatsApp as a good teaching and learning platform. A study by [33] confirm that WhatsApp can be an effective media to improve students' critical thinking skills. Many studies also prove that WhatsApp can be a tool to increase students' participation in learning [34] [35]. Activities undertaken can be in the form of discussions to practice language skills. However, teachers need to remember that choosing the most appropriate app to facilitate learning is not everything. Proper guidance plays a more pivotal role for the learning success (Hwang et al., 2015 as cited in [31].

When facilitating online debate, there are some issues teachers need to take into account. Data plan has been the main issue faced by most students since the implementation of online learning in Indonesia [13]. Furthermore, [36] point out that the sudden shift from face-to-face learning into a total online learning has become a new challenge for both teachers and students.

One issue found in a research by [33] in relation to the use of WhatsApp in learning is about time consuming and eyestrain. In another study by [37], it was found that unsupported phone and overload content become a problem for the students when being involved in learning on mobile phone. Another issue that needs to be taken into account is related to internet connection when students participate in online learning through mobile apps [38].

\section{Research Methods}

This research employed both quantitative and qualitative methods to find out students' voices towards online debate through WhatsApp as alternative media to enhance critical thinking skills during Covid-19 pandemic. Specifically, the present research tried to explore how they viewed the online debate, what benefits the activity provided, and what challenges the participants encountered during their participation. 


\subsection{Participants and Debate Procedure}

17 undergraduate students enrolling in English major at Universitas Muhammadiyah Riau took part in the online debate. The participants were selected using convenience sampling. All of them have got any experience in classroom debate and use WhatsApp in daily communication. All of the participants participated in survey questionnaire at the end of the study, but only eight participants (called as P1-P8) volunteered to become the interviewees of semi-structured interviews at the end of the research.

The online debate through WhatsApp ran for ten sessions for one whole semester. The debate method used was British Parliamentary where there were four teams in each round. Two teams were in the Government side to support the motion being debated, and the other two teams were in Opposition side to disagree with the motion. In each session, the motion was launched a few minutes before the debate started. Then the teams were given 15 minutes for case building to prepare the arguments. After 15 minutes was over, the debate began. How the debate works can be seen in Figure 1.

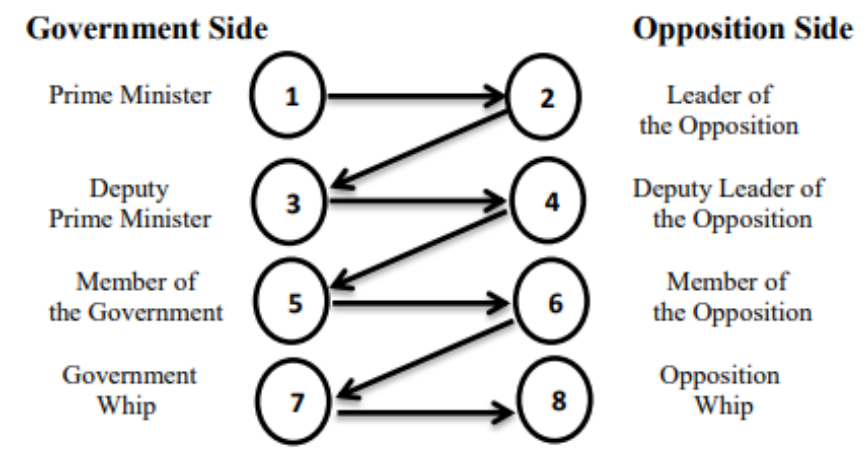

Fig. 1. Format of British Parliamentary Debate

As seen in Figure 1 above, the first to speak was Prime Minister. After the Prime Minister finished submitting an argument accompanied by data and evidence, the next turn would be the Opposition Leader. The task of the Opposition Leader was to refute the Prime Minister's statements and submit arguments accompanied by strong data and evidence. The next turn was the Deputy Prime Minister and so on until the Opposition Whip. Each speaker was given 7 minutes to deliver their arguments.

\subsection{Data Collection and Analysis}

The data were collected by employing both quantitative and qualitative approaches. A survey questionnaire and interviews were employed to collect the required data as discussed in the following sections.

Questionnaires. To collect quantitative data, a set of questionnaires was developed adapting the instruments by [17] and based on the research questions and the litera- 
ture review. The survey aimed at gathering descriptive data regarding how the respondents viewed the online debate and what benefits the activity provided. The questionnaire consisted of 15 items with a 5-point Likert scale (Strongly Disagree=1 to Strongly Agree=5) which can be seen in Table 1 of Findings section. The questionnaires were distributed and all research participants completed the survey.

Interviews. The second data of this study was taken qualitatively from semistructured interviews with eight volunteered respondents after they took part in online debate for ten times. The interview served as an opportunity for the respondents to express their impressions fully and provide a more in-depth view of the topics discussed regarding students' voices of online debate through WhatsApp as alternative media to enhance critical thinking skills during Covid-19 pandemic. More importantly, the interviews allow the researchers to triangulate the data and make the results more reliable.

The interview took place for thirty minutes and was audio-recorded. Before the interviews took place, the researchers explained the purpose of the interview and the expected duration. Permission to use the recorder was also gained. Furthermore, the researchers informed the participants that their responses would be kept confidential and anonymous would be used.

The researchers asked the participants to voice their experiences regarding the use of online debate through WhatsApp as alternative media to enhance critical thinking skills during Covid-19 pandemic. The respondents were also asked to share opinion regarding the drawbacks they encountered during the online debate.

The data from recorded interview were first transcribed, and then the transcripts were coded. Finally, appropriate extracts on the benefits and barriers voiced by the participants towards online debate through WhatsApp as alternative media to enhance critical thinking skills during Covid-19 pandemic were described in findings and discussion sections.

\section{$4 \quad$ Findings and Discussion}

This part presents the research findings from the survey questionnaire first and qualitative data from semi-structured interview afterwards.

\subsection{Quantitative Results}

Table 1 demonstrates the results of the questionnaire consisting of 15 items using a 5-point Likert scale (Strongly Disagree=1 to Strongly Agree=5).

Table 1. Results of Questionnaire

\begin{tabular}{|c|c|c|c|c|c|c|c|}
\hline \multicolumn{2}{|l|}{ Questionnaire Items } & \multicolumn{5}{|c|}{ Students' Responses } & \multirow[t]{2}{*}{ Mean } \\
\hline & & $\begin{array}{l}\text { Strongly } \\
\text { Disagree }\end{array}$ & Disagree & Neutral & Agree & $\begin{array}{c}\text { Strongly } \\
\text { Agree }\end{array}$ & \\
\hline \multirow{2}{*}{$\begin{array}{l}\text { 1. Critical thinking skill is very } \\
\text { important for students }\end{array}$} & $\mathrm{N}$ & 0 & 0 & 0 & 6 & 11 & \multirow{2}{*}{4.65} \\
\hline & $\%$ & 0 & 0 & 0 & 35.3 & 64.7 & \\
\hline
\end{tabular}


Paper-Students' Voices Towards Online Debate Through WhatsApp as Alternative Media to Enhance...

\begin{tabular}{|c|c|c|c|c|c|c|c|}
\hline \multirow{2}{*}{$\begin{array}{l}\text { 2. Online debate through } \\
\text { WhatsApp is a new way and } \\
\text { good alternative media to en- } \\
\text { hance my critical thinking skill } \\
\text { during Covid-19 pandemic }\end{array}$} & $\mathrm{N}$ & 0 & 0 & 2 & 12 & 3 & \multirow[b]{2}{*}{4.06} \\
\hline & $\%$ & 0 & 0 & 11.76 & 70.6 & 17.64 & \\
\hline \multirow{2}{*}{$\begin{array}{l}\text { 3. The online debate I did with } \\
\text { other students during this } \\
\text { Covid-19 pandemic is enjoya- } \\
\text { ble }\end{array}$} & $\mathrm{N}$ & 0 & 1 & 2 & 9 & 5 & \multirow[b]{2}{*}{4.06} \\
\hline & $\%$ & 0 & 5.9 & 11.76 & 52.94 & 29.41 & \\
\hline \multirow{2}{*}{$\begin{array}{l}\text { 4. I am willing to participate in } \\
\text { another online debate in the } \\
\text { future }\end{array}$} & $\mathrm{N}$ & 0 & 1 & 5 & 9 & 2 & \multirow{2}{*}{3.71} \\
\hline & $\%$ & 0 & 5.9 & 29.41 & 52.94 & 11.76 & \\
\hline \multirow{2}{*}{$\begin{array}{l}\text { 5. I would like to recommend } \\
\text { online debate through } \\
\text { WhatsApp to my friends }\end{array}$} & $\mathrm{N}$ & 0 & 0 & 2 & 8 & 7 & \multirow[b]{2}{*}{4.29} \\
\hline & $\%$ & 0 & 0 & 11.76 & 47.05 & 41.17 & \\
\hline \multirow{2}{*}{$\begin{array}{l}\text { 6. Online debate stimulates } \\
\text { critical thinking on the subject } \\
\text { matter }\end{array}$} & $\mathrm{N}$ & 0 & 0 & 0 & 7 & 10 & \multirow{2}{*}{4.59} \\
\hline & $\%$ & 0 & 0 & 0 & 41.17 & 58.82 & \\
\hline \multirow{2}{*}{$\begin{array}{l}\text { 7. Online debate trains me to } \\
\text { analyze the problem and find } \\
\text { possible solution }\end{array}$} & $\mathrm{N}$ & 0 & 2 & 1 & 8 & 6 & \multirow{2}{*}{5.00} \\
\hline & $\%$ & 0 & 11.76 & 5.9 & 47.05 & 35.3 & \\
\hline \multirow{2}{*}{$\begin{array}{l}\text { 8. Online debate promotes } \\
\text { teamwork and decision making } \\
\text { skill }\end{array}$} & $\mathrm{N}$ & 0 & 0 & 0 & 10 & 7 & \multirow[b]{2}{*}{4.41} \\
\hline & $\%$ & 0 & 0 & 0 & 58.82 & 41.17 & \\
\hline \multirow{2}{*}{$\begin{array}{l}\text { 9. Online debate allows the } \\
\text { participants to see the matter } \\
\text { from different perspective }\end{array}$} & $\mathrm{N}$ & & & 3 & 6 & 8 & \multirow[b]{2}{*}{4.12} \\
\hline & $\%$ & 0 & 0 & 0 & 35.3 & 47.05 & \\
\hline \multirow{2}{*}{$\begin{array}{l}\text { 10. Online debates helps the } \\
\text { students to learn to provide } \\
\text { arguments with evidence }\end{array}$} & $\mathrm{N}$ & 0 & 1 & 1 & 9 & 6 & \multirow{2}{*}{4.06} \\
\hline & $\%$ & 0 & 5.9 & 5.9 & 52.94 & 35.3 & \\
\hline \multirow{2}{*}{$\begin{array}{l}\text { 11. Online debate trains the } \\
\text { students to argue convincingly }\end{array}$} & $\mathrm{N}$ & 0 & 0 & 1 & 7 & 9 & \multirow{2}{*}{4.47} \\
\hline & $\%$ & 0 & 0 & 5.9 & 41.17 & 52.94 & \\
\hline \multirow{2}{*}{$\begin{array}{l}\text { 12. The students learn to be } \\
\text { open-minded by accepting } \\
\text { reasonable criticism from op- } \\
\text { ponents }\end{array}$} & $\mathrm{N}$ & 0 & 1 & 1 & 8 & 7 & \multirow[b]{2}{*}{4.12} \\
\hline & $\%$ & 0 & 5.9 & 5.9 & 47.05 & 41.17 & \\
\hline \multirow{2}{*}{$\begin{array}{l}\text { 13. Online debate improves } \\
\text { students' argumentation skills }\end{array}$} & $\mathrm{N}$ & 0 & 0 & 0 & 9 & 8 & \multirow{2}{*}{4.47} \\
\hline & $\%$ & 0 & 0 & 0 & 52.94 & 47.05 & \\
\hline \multirow{2}{*}{$\begin{array}{l}\text { 14. Online debate encourages } \\
\text { me to do lots of reading }\end{array}$} & $\mathrm{N}$ & 0 & 0 & 2 & 9 & 6 & \multirow{2}{*}{4.80} \\
\hline & $\%$ & 0 & 0 & 11.76 & 52.94 & 35.3 & \\
\hline \multirow{2}{*}{$\begin{array}{l}\text { 15. Online debate trains students } \\
\text { to always find credible infor- } \\
\text { mation }\end{array}$} & $\mathrm{N}$ & 0 & 0 & 0 & 7 & 10 & \multirow[b]{2}{*}{4.59} \\
\hline & $\%$ & 0 & 0 & 0 & 41.17 & 58.82 & \\
\hline \multicolumn{7}{|c|}{ Overall } & 4.36 \\
\hline
\end{tabular}

From table 1 above, it can be seen that some items are in the highest and some items are in the lowest rank in relation to students' voices towards online debate through WhatsApp as alternative media to enhance critical thinking skills during Covid-19 pandemic. Item number 7 got the highest rank with a mean score of (5.00) which demonstrates that the respondents have good attitude in relation to the use of 
online debate to train them with the ability to analyze the problem and find possible solution. Six participants strongly agree with the statement, eight participants agree, one participant is in neutral, and only two are in disagreement. Furthermore, item number 14 got the second highest rank with a mean score of (4.80) also indicating that the respondents view the online debate positively which encourages them to do lots of reading. From seventeen respondents completing the questionnaire, six of them are in a strong agreement, nine respondents agree, and the other two are in neutral position.

The questionnaire results, which can be seen from the table above, also reveal that one item got the lowest rank, and three items got the second lowest rank. Item number 4 got the lowest rank with a mean score of (3.71), and items number 2, 3, and 10 are in the same rank as the second lowest with a mean score of (4.06). Finally, the overall mean score is 4.36 which demonstrate good results regarding students' voices towards online debate through WhatsApp as alternative media to enhance critical thinking skills during Covid-19 pandemic.

\subsection{Qualitative Findings}

The results of the semi-structured interview are consistent with the questionnaire results and reveal more in-depth data. There are three themes discussed by the respondents during the interviews, namely the importance, advantages and barriers of online debate through WhatsApp as alternative media to enhance critical thinking skills during Covid-19 pandemic.

The Importance of critical thinking skills. All participants share the same view that critical thinking skills are important for today's students, for example as P2 explains below.

P2: Yes, I think it's really important especially for today's students. Pandemic has created fears, troubles, economic problems and lots of issues and hoax around us and all of that stuffs cause unsolicited conflict.

As seen above, P2 is aware of the current situation where she is always exposed to lots of information in which she needs to filter. In order not to be deceived with hoaxes or similar issues, the students need to analyze and evaluate the information they receive. The students experience this kind of learning in the online debate as stated by P7:

P7: Yes, critical thinking skills are important to help students improve their ability to analyze, solve, and even evaluate a problem because critical thinking will make students think rationally regarding the information they receive. I am really happy to participate in the online debate because I can practice the skills I mentioned.

Advantages. All of the participants believe that the online debate is a good activity to enhance their critical thinking skills, especially during this Covid-19 pandemic. During the interview, they shared their views related to the advantages of the online debate as described in more details below.

The flexibility in time and place. All participants believe that the online debate allows them to improve their critical thinking skills during Covid-19 pandemic anywhere anytime. Even though the pandemic prevents them from attending formal lec- 
ture, they can spend their time studying especially to improve their critical thinking skills at home.

P2: Yes, I believe online debate is a good way to enhance our critical thinking skills. Now, we are limited by the pandemic. Many places have been closed, and our activities also change. But it does not mean that we cannot do the activities. We still can do that, in another ways. We also can improve our knowledge, our abilities or our critical thinking in different ways, in different platforms. We can do it online, with technologies. And about the critical thinking during the covid-19, we still can do it with online, and guess what, it works. So stay smart, stay strong and stay live.

P3: In my opinion, the online debate I did was really a good way to improve my critical thinking during COVID-19 pandemic. Through the online debate, we can practice conveying our arguments without going to a place (we can do it at home) so it becomes easy and comfortable.

P4: Yes, I think it can help me to improve and build my critical thinking. During this pandemic, we spend our time at home, so I just can read a book. But after joining the online debate, I can enhance my critical thinking skills because I can share my opinion in this forum.

As explained by P2 above, Covid-19 Pandemic does not hinder students to improve their critical thinking skills as they can participate in the online debate without having to worry about time and place. P3 further states that the online debate becomes a simple and enjoyable activity to enhance the students' critical thinking skills. Sharing opinion related to various issues during this pandemic is a good activity as explained by $\mathrm{P} 4$.

Reducing anxiety. It is known that conveying opinions in front of many people is really challenging and even frustrating for most people. As a consequence, many people are not confident and encounter some problems such as being unable to express the ideas due to the crowd, sweating, being nervous, and other feelings. Online debate, on the other hand, gives less pressure to the participants. Therefore, they become less anxious since they do not face the opponents directly.

P2: Yes, the online debate is less stressful than classroom debate, I think. But, we still can get the good impacts from the online debate. Even though it is not the same with the debate I usually do, it is still fun and challenging.

P5: I think online debate can reduce our anxiety of speaking face-to-face. Besides, online debate becomes fun and enjoyable because we can rebut the opponents' arguments by providing great argument and strong evidence.

P8: In my opinion, online debate is really helpful and exciting because we are not possible to meet face-to-face at this time. This is a new thing and new experience for me. I enjoy this online debate.

The three participants above are in agreement that the online debate is a new and fun way to improve their critical thinking skills. P5 specifically points out that he can express his ideas along with strong evidences in a less anxious environment since he does not face the opponents directly.

Improving teamwork skills. Teamwork is one of the most important skills students need to master in this era. When asked about what benefits the online debate offer, the respondents believe that the online debate allows them to experience working in team. 
P1: Teamwork, of course. My teammate and I help each other to prepare the arguments, rebuttal ideas and find data.

The response from P1 above demonstrates how she works with her partner in discussing about the arguments to be delivered, and even preparing some ideas to rebut the opponents' arguments. Other participants share the same opinion and explain how the communication with her teammate occurs even though they are separated by distance.

P5: As long as online debate, I have learned a lot of things such as the importance of teamwork even we were not face to face, how important the communication is and how to analyze problems and get the appropriate solutions.

P6: Maybe I did not talk to my partner face-to-face, but I still can contact my partner. Even better, we can communicate from far places without meet each other.

Improving persuasion skills. The online debate provides a great opportunity for the students to improve their persuasion skills. During the activity, all participants should provide strong arguments aiming at persuading the audiences or even the opponents to agree with their stance. The participants share how they practice this skill in the online debate.

P1: To persuade audiences, of course I have to make my arguments reasonable with data and facts so the opposition team cannot rebut my opinion.

P2: Usually to convince the audience, I am just trying to give the aspects from their opinion as well.

P7: $\quad$ Presenting fact and real evidence that we can find in real life is the strategy we chose to convince the audience, because the audience will easily agree to our opinion if it is really happening in real life.

As explained by the three respondents above, they apply some strategies to convince the audiences, namely providing arguments supported with data, facts, and evidences.

Barriers. Apart from the importance and advantages of online debate through WhatsApp to enhance critical thinking skills, there are some barriers the participants encountered. The barriers include distraction, tendency to copy and paste, unstable network, and limited time.

Being distracted. The first barrier experienced by the participants during their participation in the online debate is some distraction since they do the activity at home. One participant shares what she experienced.

P1: When I started to prepare my arguments, I was distracted because my nephew ran back and forth and called me to play with him so that's make me confused and I can't concentrate.

Tendency to copy and paste. The next drawback of online debate, as voiced by the respondents, is there is no control from the teachers or the so-called adjudicators in conventional debate. Therefore, some participants might just copy and paste the arguments they get from various sources. Stories from the following participants show this concern.

P1 I think the students can find the arguments through many platforms. If the points, let's say, support the motion, they will just copy without analyzing first. But for some students who want to enhance their critical thinking skills, they will read the 
sources and write their arguments by their own style. So online debate will be good for students who have ambition to hone their critical thinking skills but (I'm sorry I have to say this) it can be useless for students who do not want to improve their critical thinking

P3: The challenges that I faced was I have to force myself to not copy the answer from the internet

Unstable network. The next barrier the participants encounter during the online debate is related to the unstable network.

P2: Network. Yes, that is the challenge. When I want to communicate with my partner and the signals is lost I just felt like I have got a heart attack, and then I am screaming "Oh my goodness why you gone now?".

P3: The signal is the serious issue due to this debate. We need the stable signal

The stories from two participants above demonstrate how good network plays a pivotal role in making the online debate run well. The participants, however, encountered bad network during their participation. As a consequence, it distracts their activity.

Limited time. The last barrier as shared by the respondents is regarding the time. Based on the interview results, the participants think that the time to prepare and share their arguments is limited.

P4: I think challenges that I got during online debate is the limited time to types my argument and the error internet connection.

P5: The challenges are signal error or less quota and waiting for the opposition side to type their arguments.

P6: The challenge I face is the internet network, because sometimes when we want to find theories and network problems it makes me anxious. Because time is limited and also the turn is getting closer, and sometimes incoming messages are delayed so we don't know to what extent the debate has taken place in groups

\subsection{Discussion}

Advantages. One very important skill today's students need to have is the ability to think critically [17] [21] [20]. The results from both questionnaire and semistructured interviews of the present study reveal that all participants share the same view that critical thinking skills are important for them. They further state that they enjoy participating in the online debate to enhance their critical thinking skills. The online debate allows them to practice critical thinking skills which help them solve some issues during Covid-19 pandemic.

The participants of the present study view online debate beneficial to enhance their critical thinking skills. This is in line with the research finding by [17] where critical thinking skills can be honed through debate. During the interview, the participants discussed about some benefits they got from the activity. First of all, they talked about the utilization of technology. As known that technology can be utilized to improve student's performances [25]. This is due to the fact that students are now accustomed to using technology such as computers and cellphones to support learning activities [39]. 
With technology, students can get information quickly and be able to learn anywhere anytime [30]. As a result, teaching and learning can be more flexible especially in terms of interaction and communication among students [27]. All participants in the present study believe that the online debate through whatsapp allows them to improve their critical thinking skills anywhere anytime. Even though the covid-19 pandemic prevents them from attending formal lecture, they can spend their time studying especially to improve their critical thinking skills at home. In other words, covid-19 Pandemic does not hinder students to improve their critical thinking skills as they can participate in the online debate without having to worry about time and place.

The second benefit the participants see from the online debate is to reduce anxiety. The participants point out the online debate gives less pressure to them. Therefore, they become less anxious since they do not face the opponents directly. They are in agreement that the online debate is a fun place to improve their critical thinking skills.

The next advantage of the online debate, as claimed by the participants, is related to improving teamwork skill. The respondents believe that the online debate allows them to experience working in team. Furthermore, the online debate is a good platform to practice students teamwork skills and even increase self-confidence [17]. This is what the participants share in the interview. They further state that during the debate they have to work in team preparing and delivering their arguments. Not only that, they provide the arguments with concrete evidence to convince the listener. This is in line with what [40] found. Moreover, the activities the participants do to express opinions, make decisions based on reliable data sources [40], argue and defend their position [3] are certainly required to improve critical thinking skills.

Improving persuasion skill is another benefit of online debate as shared by the participants. During the activity, all participants provided strong arguments aiming at persuading the audiences or even the opponents to agree with their stance. This activity trains them to be critical thinkers. As known that people are considered to have critical thinking skill when being able to change the attitude of others with the arguments and evidence presented [8].

The students in the present study also have to do several things as explained by Patterson (2011) in [18] and [19]. During the online debate, the participants share how they should first of all do some research to understand the motion and prepare arguments, find some facts and evidences to support their arguments, evaluate and choose what arguments to be used, and finally convey the arguments to the audiences.

Barriers. Apart from some advantages offered by online debate to enhance students' critical thinking skills, during the interviews the participants shared some barriers they encountered during the online debate activity. This is understandable as [36] point out that the sudden shift from face-to-face learning into a total online learning has become a new challenge for both teachers and students. A research by [30] found that many students encountered some problems when participating online learning such as getting distracted. This issue was faced by one of the participants in the present study. The participant shared how the place could affect her participation on the online debate. She further stated that her distraction was due to the noise and unexpected problem from the surrounding area. 
Proper guidance plays a pivotal role for the learning success (Hwang et al., 2015 as cited in [31] when integrating mobile apps, in this case WhatsApp in learning process. If the teachers do not clearly explain the learning procedures, there will be some problems occurring during the learning. This is a concern by the participants of the online debate. In the interview, they stated how the debate participants might be tempted to just copy and paste from some sources and claimed as their own arguments.

Another issue that needs to be taken into account is related to internet connection when students participate in online learning through mobile apps [38]. This was mentioned by the participants during the interview where they struggled to find sources and conveyed arguments due to unstable network in their respective area. The stories from participants in the present study demonstrate how good network plays a pivotal role in making the online debate run well.

Last but not least, time consuming becomes an issue when using WhatsApp in learning process [33]. The interviewees shared how they struggled to type the arguments on their mobile phone, and many times they encountered error Internet connection. As a consequence, they had to wait and did not have enough time to convey complete arguments during the online debate.

\section{Conclusion}

The present study has explored the voices of university students regarding their involvement in online debate to enhance their critical thinking skills during Covid-19 pandemic. The results from both quantitative and qualitative data are in consistent that all of the participants in the present study agree that they need to enhance critical thinking skill as these skills are important nowadays. The participants discuss about some benefits they get as well as the drawbacks from the activity.

The respondents believe that the online debate is good learning media to help them improve their critical thinking skills during this Covid-19 pandemic. Furthermore, the participants share how they can do the activity without having to worry about time and place since the activity is carried out online. It is also found that the participants become less anxious during the online debate. Teamwork and persuasion skills are other areas that can be developed during the activity, as claimed by the participants. However, some barriers were also found based on the participants' responses. The participants are concerned with the issue of being distracted, tendency to copy and paste, unstable network, and limited time. Furthermore, the research results contribute in a way to enrich existing literature regarding the use of debate to enhance critical thinking skills, especially in online setting which enables the participants to take part regardless wherever they are.

However, the present study has some limitations. First of all, the participants are university students residing in a city and with a small number of participants. Involving more respondents and from different level of study or areas may prompt different outcomes. Second, this research just focused on figuring out the benefits and barriers of online debate through WhatsApp to enhance critical thinking skills as voiced by the 
Paper-Students' Voices Towards Online Debate Through WhatsApp as Alternative Media to Enhance...

respondents. Therefore, further research needs to be carried out by figuring out the improvement of students' critical thinking skills before and after the treatment.

\section{Acknowledgement}

The researchers would like to express gratitude to those who have played a role in this research, especially to the Deputy for Strengthening Research and Development of the Ministry of Research and Technology/the National Research and Innovation Agency through LLDIKTI Region $\mathrm{X}$ in accordance with the Research Contract Number:084/LL10/PG/2020. Our gratitude also goes to the Institute for Research and Community Services of Universitas Muhammadiyah Riau.

\section{$7 \quad$ References}

[1] A. C. Saputri, Sajidan, Y. Rinanto, Afandi, and N. M. Prasetyanti, "Improving students' critical thinking skills in cell-metabolism learning using Stimulating Higher Order Thinking Skills model," Int. J. Instr., vol. 12, no. 1, pp. 327-342, 2019, https://doi.org/10.29333/iji.2019.12122a

[2] S. Y. Foo and C. L. Quek, "Developing student' critical thinking through asynchronous online discussions : A literature review," Malaysian Online J. Educ. Technol., vol. 7, no. 2, pp. 37-58, 2019. https://doi.org/10.17220/mojet.2019.02.003

[3] J. Fuad, I. W. Ardana, - Sulton, and D. Kuswandi, "Increasing Critical Thinking Skill Through Class Debate," Atl. Press, pp. 38-42, 2016, https://doi.org/10.2991/icse$\underline{15.2016 .9}$

[4] F. Aryani, M. Rais, and H. Wirawan, "Reflective learning model in improving student critical thinking skills," Glob. J. Eng. Educ., vol. 19, no. 1, pp. 19-23, 2017.

[5] D. Ratnadewi and S. Yunianti, "Indonesian student teachers' critical thinking skills in text analysis with CDA approach," Humanit. Soc. Sci. Rev., vol. 7, no. 3, pp. 424-431, 2019, https://doi.org/10.18510/hssr.2019.7362

[6] E. Junining, "Developing Critical Thinking Skills in Language Teaching: Oral Interpretation Class," Pros. Ictte Fkip Uns 2015, vol. 1, no. 1, pp. 870-873, 2016.

[7] S. Mahanal, S. Zubaidah, I. D. Sumiati, T. M. Sari, and N. Ismirawati, "RICOSRE: A learning model to develop critical thinking skills for students with different academic abilities," Int. J. Instr., vol. 12, no. 2, pp. 417-434, 2019, https://doi.org/10.29333/ iji.2019.12227a

[8] J. N. Iman, "Debate Instruction in EFL Classroom: Impacts on the Critical Thinking and Speaking Skill," Int. J. Instr., vol. 10, no. 4, pp. 87-108, 2017, https://doi.org/10.12973/ iji.2017.1046a

[9] R. Indah and A. Kusuma, "Factors Affecting the Development of Critical Thinking of Indonesian Learners of English Language," J. Humanit. Soc. Sci., vol. 21, no. 6, pp. 8694, 2016.

[10] N. Velayati, A. Muslem, S. S. Fitriani, and I. A. Samad, "An Exploration of Students' Difficulties in Using Critical Thinking Skills in Reading," Al-Ta lim J., vol. 24, no. 3, pp. 195-206, 2017, https://doi.org/10.15548/jt.v24i3.298 
[11] I. Irwan, M. Maridi, and S. Dwiastuti, "Developing guided inquiry-based ecosystem module to improve students' critical thinking skills," J. Pendidik. Biol. Indones., vol. 5, no. 1, pp. 51-60, 2019, https://doi.org/10.22219/jpbi.v5i1.7287

[12] UNICEF, "COVID-19 and Children in Indonesia," 2020.

[13] Gunawan, N. M. Y. Suranti, and Fathoroni, "Variations of Models and Learning Platforms for Prospective Teachers During the COVID-19 Pandemic Period," Indones. J. Teach. Educ., vol. 1, no. 2, pp. 61-70, 2020.

[14] B. L. Moorhouse, "Adaptations to a face-to-face initial teacher education course 'forced' online due to the COVID-19 pandemic," J. Educ. Teach., vol. 00, no. 00, pp. 1-3, 2020, https://doi.org/10.1080/02607476.2020.1755205

[15] Mendikbud, "Surat Edaran Mendikbud: Pelaksanaan Kebijakan Pendidikan dalam Masa Darurat Penyebaran Corona Virus Disease (COVID-19)," 2020.

[16] S. Altam, "Influence of social media on EFL Yemeni learners in Indian Universities during Covid-19 Pandemic," Linguist. Cult. Rev., vol. 4, no. 1, pp. 35-47, 2020, doi: https://doi.org/10.37028/lingcure.v4n1.19.

[17] P. Zare and M. Othman, "Students' perceptions toward using classroom debate to develop critical thinking and oral communication ability," Asian Soc. Sci., vol. 11, no. 9, pp. 158170, 2015, https://doi.org/10.5539/ass.v11n9p158

[18] M. A. Tawil, "Classroom Debates: A Tool to Enhance Critical Thinking in Science," Mont. State Univ., 2016

[19] S. Wahyuni, Erman, S. Y. Sudikan, and B. Jatmiko, "Edmodo-Based Interactive Teaching Materials as an Alternative Media for Science Learning to Improve Critical Thinking Skills of Junior High School Students," Int. J. Interact. Mob. Technol., vol. 14, no. 9, pp. 166-181, 2020. https://doi.org/10.3991/ijim.v14i09.13041

[20] J. Ikhsan, K. H. Sugiyarto, and T. N. Astuti, "Fostering student's critical thinking through a virtual reality laboratory," Int. J. Interact. Mob. Technol., vol. 14, no. 8, pp. 183-195, 2020, https://doi.org/10.3991/ijim.v14i08.13069

[21] Haerazi, I. M. P. Utama, and H. Hidayatullah, "Mobile applications to improve english writing skills viewed from critical thinking ability for pre-service teachers," Int. J. Interact. Mob. Technol., vol. 14, no. 7, pp. 58-72, 2020, https://doi.org/10.3991/ijim.v14 $\underline{\mathrm{i} 07.11900}$

[22] L. M. . Badie, "Demonstrating the Impact of Brainstorming Technique on EFL Students and Its Consequences for Improving the Creativity of Solving-Problems during Times of Covid-19 Pandemic," J. Tikrit Univ. Humanit., vol. 27, no. 5, pp. 33-44, 2020.

[23] D. Darmawansah, "Using WhatsApp To Extend English Debate Learning: An Interpretative Case Study Among Undergraduate Students," no. November, 2019.

[24] Q. Li, Y. Li, and Y. Shen, "Impacts of debate instruction on students' critical thinking skills in College EFL Classes: An empirical investigation," J. Phys. Conf. Ser., vol. 1629, no. 1, 2020, https://doi.org/10.1088/1742-6596/1629/1/012104

[25] I. F. Rahmadi, "WhatsApp Group for Teaching and Learning in Indonesian Higher Education," Int. J. Interact. Mob. Technol., vol. 14, no. 13, pp. 150-160, 2020. https://doi.org/10.3991/ijim.v14i13.14121

[26] S. Papadakis, M. Kalogiannakis, E. Sifaki, and N. Vidakis, "Evaluating Moodle use via Smart Mobile Phones. A case study in a Greek University," EAI Endorsed Trans. Creat. Technol., vol. 5, no. 16, p. 156382, 2018, https://doi.org/10.4108/eai.10-4-2018.156382

[27] Pahmi and W. Syafutra, "Development of Learning Media Using VideoScribe for the Subject of Present Continuous Tense," Lect. J. Pendidik., vol. 10, no. 2, pp. 184-197, 2019, https://doi.org/10.31849/lectura.v10i2.3129 
[28] S. Papadakis, M. Kalogiannakis, E. Sifaki, and N. Vidakis, "Access moodle using smart mobile phones. A case study in a greek university," Lect. Notes Inst. Comput. Sci. Soc. Telecommun. Eng. LNICST, vol. 229, no. June, pp. 376-385, 2018, https://doi.org/10.10 07/978-3-319-76908-0_36

[29] K. R. M. Rafiq, H. Hashim, M. Md Yunus, and H. Norman, “iSPEAK: Using mobilebased online learning course to learn 'english for the workplace,"” Int. J. Interact. Mob. Technol., vol. 14, no. 8, pp. 19-31, 2020, https://doi.org/10.3991/ijim.v14i08.13185

[30] Pahmi, S. Niah, and N. Edjuista, "The Utilization of Mobile Technologies in ELT: Voices from English Course Teachers,” vol. 373, pp. 49-53, 2019, https://doi.org/10.2991/iccelst$\underline{\text { ss-19.2019.11 }}$

[31] S. Papadakis and M. Kalogiannakis, "Mobile educational applications for children. What educators and parents need to know.," Int. J. Mob. Learn. Organ., vol. 11, no. 2, p. 1, 2017, https://doi.org/10.1504/ijmlo.2017.10003925

[32] S. Papadakis, J. Vaiopoulou, M. Kalogiannakis, and D. Stamovlasis, "Developing and exploring an evaluation tool for educational apps (E.T.E.A.) targeting kindergarten children," Sustain., vol. 12, no. 10, pp. 1-10, 2020, https://doi.org/10.3390/su12104201

[33] R. Kustijono and F. Zuhri, "The use of Facebook and WhatsApp application in learning process of physics to train students' critical thinking skills," IOP Conf. Ser. Mater. Sci. Eng., vol. 296, no. 1, 2018, https://doi.org/10.1088/1757-899x/296/1/012025

[34] S. F. Fattah, "The Effectiveness of Using WhatsApp Messenger as One of Mobile Learning Techniques to Develop Students' Writing Skills," J. Educ. Pract., vol. 6, no. 32, pp. 115-127, 2015.

[35] I. Mistar and M. A. Embi, "Students' Perception on the Use of Whatsapp As a Learning Tool in Esl Classroom," J. Educ. Soc. Sci., vol. 4, pp. 96-104, 2016.

[36] A. E. P. Atmojo and A. Nugroho, "EFL Classes Must Go Online! Teaching Activities and Challenges during COVID-19 Pandemic in Indonesia," Regist. J., vol. 13, no. 1, pp. 4977, 2020, https://doi.org/10.18326/rgt.v13i1.49-76

[37] P. Pahmi, "Students' Perceptions of Using Mobile Phones and Smart Phones in Language Learning," no. August 2016, 2016.

[38] W. Kusmaryani, B. Musthafa, and P. Purnawarman, "The influence of mobile applications on students' speaking skill and critical thinking in English language learning," J. Phys. Conf. Ser., vol. 1193, no. 1, 2019, https://doi.org/10.1088/1742-6596/1193/1/012008

\section{Authors}

Pahmi is a lecturer at Department of English Education, Universitas Muhammadiyah Riau. He often works as the committee of International Conferences, such as CELSciTech International Conference in 2019 acting as the Conference Chair. His research interests are in the area of Teacher Education, English Teaching and Methodology, and ICT in ELT.

Siti Niah is a lecturer at Department of English Education, Universitas Muhammadiyah Riau. Her research interests are in the area of Teacher Education and Educational Technology.

Article submitted 2020-09-22 Resubmitted 2020-11-17. Final acceptance 2020-11-19. Final version published as submitted by the authors. 